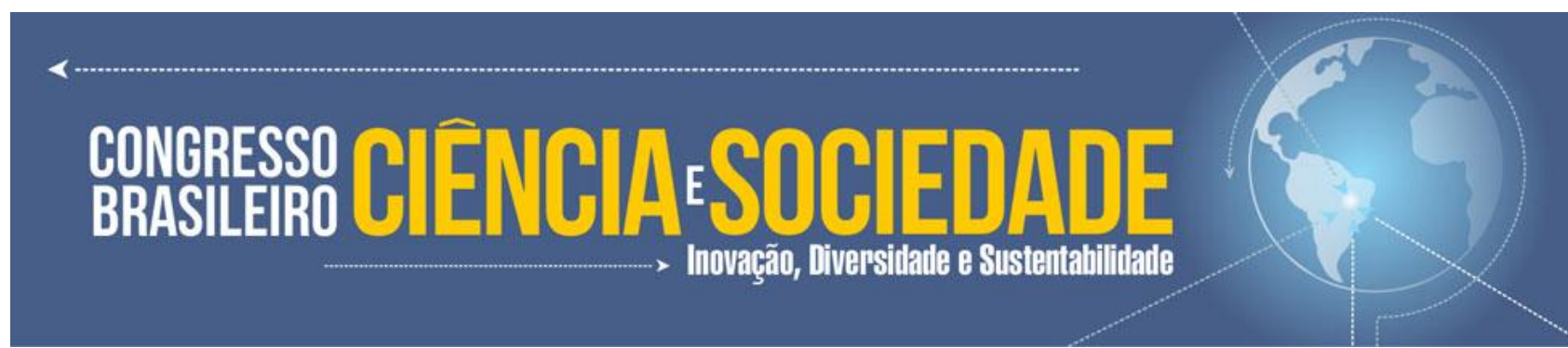

ANAIS CBCS 2019 | 3 a 5 de outubro de 2019 | Centro Universitário Santo Agostinho - Teresina - PI

\title{
LEITURA, ESCRITA E INTERTEXTUALIDADE: MECANISMOS DE CONSTRUÇÃO DE SENTIDOS COMPARTILHADOS SOBRE E COM O TEXTO ${ }^{1}$
}

\author{
Francisco Renato Lima (UFPI) ${ }^{2}$
}

\section{RESUMO}

Que a natureza da linguagem é fluída, dinâmica, interativa, dialógica e responsiva é saber teóricoepistemológico, que a partir do final do século passado tornou-se relativamente consolidado em nossa área de estudo, a Linguística. Neste sentido, encampados por essa vertente, a proposta deste estudo é analisar o modo como os textos dialogam entre si no processo de constituição e de construção de sentidos; a partir da análise de mecanismos discursivos e textuais que contribuem para a construção do fenômeno da intertextualidade explícita e implícita em textos verbais e não verbais. Atemo-nos, a partir desse recorte, a aplicar os postulados de Fiorin (2014), Koch (2015), Koch; Bentes; Cavalcante (2012), Paulino; Walty; Cury (2005), numa tentativa de elucidar as considerações em torno da complexidade que envolve o diálogos entre os textos na sociedade. Metodologicamente, situamo-nos nos liames da pesquisa bibliográfica, de caráter exploratório. As análises aqui propostas validam o entendimento de que o funcionamento da linguagem opera por meio de enlaces de vozes, que explícitas ou implícitas, vão, como espécies de aranhas, construindo suas teias, por meio de textos e discursos. Ora mais velados, ora mais "disfarçados", essas marcas ou pistas instituem o caráter da intertextualidade, sustentando os sentidos dos textos, nas fronteiras da história, da ideologia, da cultura e da marcas sociais que determinaram/influenciaram sua construção (oral ou escrita).

Palavras-Chave: Leitura. Escrita. Intertextualidade. Texto. Construção de sentidos.

\begin{abstract}
That the nature of language is fluid, dynamic, interactive, dialogical and responsive is theoreticalepistemological knowledge, which from the end of the last century has become relatively consolidated in our area of study, Linguistics. In this sense, supported by this aspect, the purpose of this study is to analyze the way the texts dialogue with each other in the process of constitution and construction of meanings; from the analysis of discursive and textual mechanisms that contribute to the construction of the phenomenon of explicit and implicit intertextuality in verbal and nonverbal texts. Let us, from this clipping, apply ourselves to postulates; Fiorin (2014), Koch (2015), Koch; Bentes; Cavalcante (2012), Paulino; Walty; Cury (2005), in an attempt to elucidate the considerations around the complexity that involves the dialogues between texts in society. Methodologically, we are located in the lines of the bibliographical research, of exploratory character. The analyzes proposed here validate the understanding that the functioning of language operates through links of voices, which explicit or implicit, go, like spider species, building their webs, through texts and discourses. More veiled, sometimes more "disguised", these marks or clues establish the character of intertextuality, sustaining the meanings of the texts, at the borders of history, ideology, culture and social marks that determined / influenced their construction (oral or written).
\end{abstract}

Keywords: Reading. Writing. Intertextuality. Text. Construction of senses.

\footnotetext{
1 Trabalho apresentado no Congresso Brasileiro Ciência e Sociedade (CBCS 2019), promovido pelo Centro Universitário Santo Agostinho, de 03 a 05 de outubro de 2019, em Teresina-PI.

${ }^{2}$ Mestre em Letras - Estudos da Linguagem. Atualmente é Professor Substituto, Classe Auxiliar, Nível - I, da Universidade Federal do Piauí (UFPI). E-mail: fcorenatolima@hotmail.com

ISBN: 978-65-80968-11-4 DOI: $10.17648 / \mathrm{cbcs}-2019-110586$
} 
ANAIS CBCS 2019 | 3 a 5 de outubro de 2019 | Centro Universitário Santo Agostinho - Teresina - P

\title{
CONSIDERAÇÕES INICIAIS
}

A apropriação da voz do outro é um mecanismo, na verdade, de evidenciar que não estamos sozinhos em nossos movimentos discursivos no mundo da leitura e da escrita. Recorremos a outros, para, de maneira ativa e dialógica, balizar nosso dizer, emparelhá-lo a um discurso já aceito socialmente, afinal, "todo falante é por si mesmo um respondente em maior ou menor grau" (BAKHTIN, 2011, p. 272), pois "uma só voz nada termina e nada resolve. Duas vozes são o mínimo de vida, o mínimo de existência" (BAKHTIN, 2013, p. 293). A esse movimento de entrelaçamento de vozes, denominamos de intertextualidade, num plano da dimensão textual; ou interdiscusividade, num plano da dimensão discursiva, considerando que àquela se submete a esta, uma vez que os textos são frutos dos discursos. Fiorin (2014, p. 181) nos ajuda a entender melhor essa questão:

\begin{abstract}
Há claramente uma distinção entre as relações dialógicas e aquelas que se dão entre textos. Por isso, chamaremos qualquer relação dialógica, na medida em que é uma relação de sentido, interdiscursiva. $O$ termo intertextualidade fica reservado apenas para os casos em que a relação discursiva é materializada em textos. Isso significa que a intertextualidade pressupõe sempre uma interdiscursividade, mas que o contrário não é verdadeiro. Por exemplo, quando a relação dialógica não se manifesta no texto, temos interdiscursividade, mas não intertextualidade. (Grifo do autor)
\end{abstract}

Depreendemos, a partir disso, que o diálogo é a ordem funcional dos textos. Por conta disso, diversas áreas ou campos do conhecimento, como a Linguística, a Literatura, a Psicologia, a Filologia, a Semiologia etc., tem-no como tema recorrente em suas pesquisas. No entrelace das vozes que compõem os estudos nessas áreas fala-se em intertextualidade, como processo inerente a natureza funcional e constitutiva do aspecto textual-discursivo dos textos, aqui entendido resultado da intenção do autor e do contexto no qual se insere.

Desta feita, aceitamos a premissa de que toda produção textual traz em sua natureza a intertextualidade, visto que todo texto é uma remissão a outro, uma releitura daquilo que o autor vivencia no seu contexto histórico, político, sociocultural, linguístico e ideológico. Com base nisso, é que se considera que não existem textos puros, mas co-construções cooperativas entre 
ANAIS CBCS 2019 | 3 a 5 de outubro de 2019 | Centro Universitário Santo Agostinho - Teresina - P

produtores e receptores de textos - que de maneira ativa e responsiva - entrecruzam suas vozes, ainda que em tempos e espaços distintos na linha cronológica do tempo.

Cientes desses processos, a proposta deste texto é analisar o modo como os textos dialogam entre si no processo de constituição e de construção de sentidos; a partir da análise de mecanismos discursivos e textuais que contribuem para a construção do fenômeno da intertextualidade explícita e da intertextualidade implícita em textos verbais e não verbais.

A proposta em $\mathrm{si}^{3}$, não contém uma inovação às discussões sobre tema, no entanto, acrescenta-as, na medida em que compartilha dos princípios teórico-metodológicos de autores, como Fiorin (2014), Koch (2015), Koch; Bentes; Cavalcante (2012), Paulino; Walty; Cury (2005), entre outros, buscando então, aplicar suas reflexões à textos do mundo real e do cotidiano.

\section{LEITURA, ESCRITA E INTERTEXTUALIDADE: MECANISMOS DE DIÁLOGOS ENTRE OS TEXTOS}

As próprias ideias nem sempre conservam o nome do pai; muitas vezes aparecem órfãs, nascidas de nada e de ninguém. Cada um pega delas, verte-as como pode, e vai levá-las à feira, onde todos as têm por suas.

(Machado de Assis, 1994, p. 43)

Como diz nosso mestre maior da arte da palavra proseada brasileira, Machado de Assis, as ideias sempre têm um pai, uma fonte, uma origem. Ainda que não carreguem explicitamente seu nome ou sobrenome, é possível sempre encontrar reminiscências e traços implícitos, que sinalizam reconhecimento dessa familiaridade. Essa identificação, é claro, depende do olhar atento do leitor, para, no trajeto da leitura, enxergar esses rastros. É essa, portanto, a natureza dos processos de intertextualidade, que, de maneira explícita ou implícita, conserva as vicissitudes daquele que a originou, do "pai".

Ainda que, muitas haja uma tentativa de "manipulação" do "DNA" do texto alheio, recurso muito utilizado pela publicidade, pelo humor, pelas canções populares, entre outras produções

\footnotetext{
${ }^{3}$ As ideias apresentadas neste texto têm sua gênese em uma atividade apresentada à disciplina Leitura e Produção de Texto I, do 10 período do curso de Letras - Português e Francês, da Universidade Federal do Piauí (UFPI), semestre 2013.1, ministrada pela professora Dra. Maria Angélica Freire de Carvalho, a quem sou grato sempre. No entanto, assumo a responsabilidade sobre todo seu conteúdo. 
ANAIS CBCS 2019 | 3 a 5 de outubro de 2019 | Centro Universitário Santo Agostinho - Teresina - P

artísticas e culturais, com o propósito de transmitir uma informação, provocar humor, enfim, atrair a atenção do leitor, quase sempre é possível encontrar uma pista, um rastro do genitor desse texto. No entanto, para que esse reconhecimento de pistas seja possível, é necessário também, que o leitor tenha habilidades proficientes sobre o texto em questão.

Nesse ínterim, pensamos no historiador Roger Chartier (1998), que na obra: "A aventura do livro: do leitor ao navegador" nos leva a refletir que, contexto atual, especialmente, a atividade de leitura pressupõe verdadeiros caçadores, na acepção daquele que persegue, tem faro e instinto para escarafunchar as entrelinhas do texto - oral ou escrito - e em muitos formatos multissemióticos - com o propósito de aproximar-se das facetas, sutilezas e miudezas que constituem o seu sentido. No contexto escolar, esse propósito torna-se viável mediante as práticas de leitura, escrita e reescrita textual, identificando as marcas implícitas e explícitas do produtor.

Esse produtor, no momento da escrita, lança mão de estratégias e recursos linguísticodiscursivos que vão de encontro, sobretudo, aos conhecimentos de mundo que o leitor possui, considerando a máxima freireana de que "a leitura do mundo precede sempre a leitura da palavra e a leitura desta implica a continuidade da leitura daquele" (FREIRE, 2011, p. 29), criando assim, um movimento dialógico entre produtor (que tem uma intenção), texto (materialização de sua intenção) e o leitor (receptor ativo e responsivo dessa intenção), cumprindo, por fim, o princípio ativo responsivo da linguagem de Bakhtin (2009).

\footnotetext{
O enunciado nunca é apenas um reflexo, uma expressão de algo já existente fora dele, dado e acabado. Ele sempre cria algo que não existia antes dele, absolutamente novo e singular, e que ainda por cima tem relação com o valor (com a verdade, com a bondade, com a beleza, etc.). Contudo, alguma coisa criada é sempre criada a partir de algo dado (a linguagem, o fenômeno observado da realidade, um sentimento vivenciado, o próprio sujeito falante, o acabado em sua visão de mundo, etc.). Todo o dado se transforma em criado (BAKHTIN, 2011, p. 326).
}

Cabe ao leitor, portanto, a interação com o texto (falado ou escrito) e o contexto que o circunda. O conhecimento partilhado com o leitor é ativado no momento da leitura, visando à compreensão do que está sendo proposto. O produtor sinaliza para o leitor a que texto faz remissão, e, principalmente, mostra o que pretende com a atividade intertextual. 


\title{
CONGBESSO CIENCIAESOCIEDADE

ANAIS CBCS 2019 | 3 a 5 de outubro de 2019 | Centro Universitário Santo Agostinho - Teresina - P

O processo de intertextualidade é constituído da não-explicitação (implícita) ou intertextualidade explícita da fonte do texto. No primeiro caso, o autor não sinaliza diretamente a que texto remete; no segundo caso, as informações que identificam a fonte de origem, estão claras no texto. Koch; Bentes; Cavalcante (2012, p. 28-29) explicam bem esses movimentos textuaisdiscursivos: "a intertextualidade será explícita quando, no próprio texto, é feita a menção a fonte do intertexto, isto é, quando um outro texto é citado, é atribuído a outro enunciador; ou seja, quando é reportado como tendo sido dito por outro ou por outros generalizados".

Quanto a intertextualidade implícita, é, segundo as autoras, bem mais "complexa" que a primeira. Ela ocorre quando "se introduz, no próprio texto, intertexto alheio, sem qualquer menção explícita da fonte, com o objetivo quer de seguir-lhe a orientação argumentativa, quer de contraditá-lo, colocá-lo em questão, de ridicularizá-lo ou argumentar em sentido contrário” (KOCH; BENTES; CAVALCANTE, 2012, p. 31). Vejamos o que Koch (2015) diz sobre esses processos:

\begin{abstract}
A intertextualidade será explícita quando, no próprio texto, é feita a menção da fonte do intertexto, como acontece nas citações, referências, menções resumos, resenhas e traduções, na argumentação por recurso à autoridade, em como, em se tratando de situações face a face, nas retomadas do texto do parceiro, para encadear sobre ele ou contraditá-lo. (KOCH, 2015, p. 143)
\end{abstract}

Em se tratando de intertextualidade implícita, o que ocorre, de maneira geral, é que o produtor do texto espera que o leitor/ouvinte seja capaz de reconhecer a presença do intertexto, pela ativação do texto-fonte em sua memória discursiva, visto que, se tal não ocorrer, estará prejudicando a construção do sentido. (KOCH, 2015, p. 144)

Além desses dois, as próprias autoras (KOCH; BENTES; CAVALCANTE, 2012, sobretudo), assim como demais estudos (FIORIN, 2014; PAULINO; WALTY; CURY, 2005), apresentam outros mecanismos ou estratégias de diálogo (intertextualidade) entre textos, e, embora reconheçamos a diversidade dessas possibilidades de intertextualidade e seus conceitos (citados ou não neste referencial teórico, por exemplo: Barros; Fiorin (1994); Koch (1986)), na seção a seguir, exploraremos apenas, exemplos de intertextualidade explícita e implícita em textos diversos. 


\section{gowpresSO CIENCIASSOCIEDADE

ANAIS CBCS 2019 | 3 a 5 de outubro de 2019 | Centro Universitário Santo Agostinho - Teresina - PI

\section{PERSEGUINDO RASTROS DE MARCAS DE INTERTEXTUALIDADE EM TEXTOS VERBAIS E NÃO- VERBAIS: ALGUNS EXEMPLOS E ANÁLISES}

$\mathrm{Na}$ análise, apresentamos alguns exemplos, escolhidos aleatoriamente em materiais didáticos ou na Internet, que explicitem o funcionamento da intertextualidade explícita e implícita.

\section{Intertextualidade explícita em textos verbais: exemplo I}
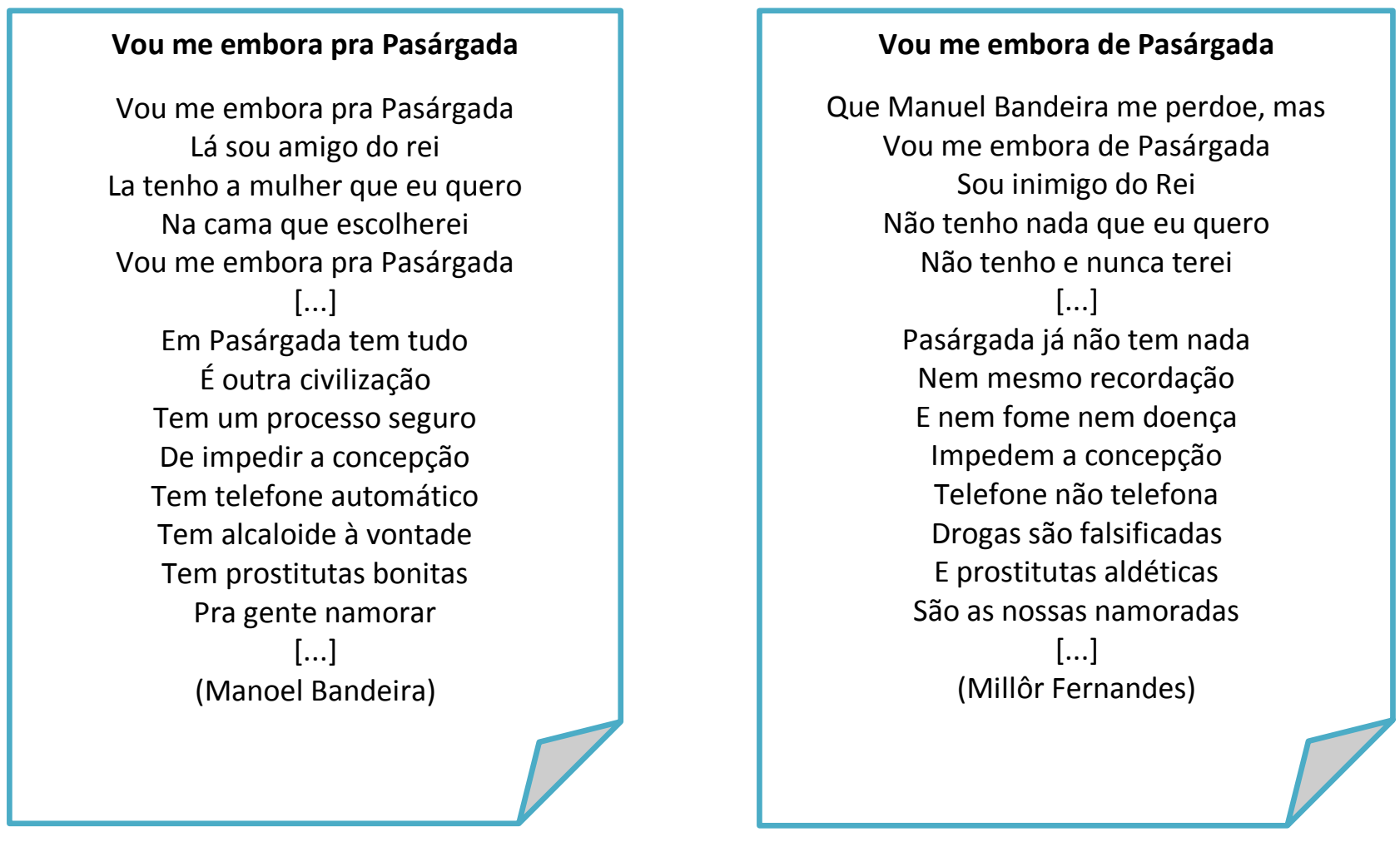

Neste caso, há uma intertextualidade explícita, pois Millôr Fernandes ao escrever seu poema, como uma "resposta" contraditória ao texto original, de Manoel Bandeira, utiliza, muitas vezes, as palavras do próprio Bandeira, fazendo com que o leitor compreenda diretamente a fonte que deu origem aquele texto. Embora separados pelo tempo (o texto de Bandeira é de 1986; e o de Millôr é de 2001, portanto, 15 anos os distanciam), os poemas conservam entre si, as propriedades textuais-discursivas que garantem ao leitor, fazer remissão um ao outro. 


\section{CONGEESSO CIENCIAESOCIEDADE \\ Inovação, Diversiliaile e Sustentahililitaile}

ANAIS CBCS 2019 | 3 a 5 de outubro de 2019 | Centro Universitário Santo Agostinho - Teresina - P

\section{Intertextualidade explícita em textos verbais e não verbais: exemplo II}

Hino Nacional Brasileiro
(Letra: Joaquim Osório Duque Estrada / Música:
Francisco Manuel da Silva)
Parte I
Ouviram do Ipiranga as margens plácidas
De um povo heróico o brado retumbante,
E o sol da liberdade, em raios fúlgidos,
Brilhou no céu da pátria nesse instante.
Se o penhor dessa igualdade
Conseguimos conquistar com braço forte,
Em teu seio, ó liberdade,
Desafia o nosso peito a própria morte!
Ó Pátria amada,
Idolatrada,
Salve! Salve!
Brasil, um sonho intenso, um raio vívido
De amor e de esperança à terra desce,
Se em teu formoso céu, risonho e límpido,
A imagem do Cruzeiro resplandece.
Gigante pela própria natureza,
És belo, és forte, impávido colosso,
E o teu futuro espelha essa grandeza.
Terra adorada,
Entre outras mil,
És tu, Brasil,
Ó Pátria amada!
Dos filhos deste solo és mãe gentil,
Pátria amada,
Brasil!

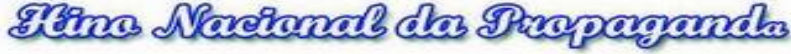

aguarce a introcucso

Num pasta da I Ipiranga, as margens plácidas,

De um Eorvo feróica BiIHW'A retumbante

(swor) da liberdade em rempe fulgida

Brilfau na Sit Shell da

Se a Frnorr dessa igualdade

Canseguimas canquistar cam braça Foxd

Em teu SEIISO, an liberdade

Desafia a nassa peita a WHGrosoit

of parmalat, Mastercan, Salue $a$ SIARPR.

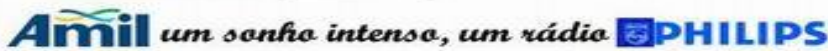

De amar a Lufthansa a terra desce

(intel famasa céu visanha Des OLYMIIKUS.

a imagem da banespa resplandesce!

Gllette pela própria natureza

Es bela, és Ooxd impávida calassa

E a teu futura espelfa essa $(\rightarrow)$ gradiente

लाओंश口 gelada

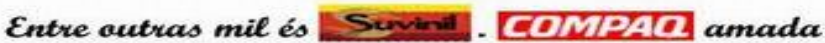

Da Phillę deste sala és mãe morar.

cargat: BOM !n!

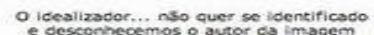

O primeiro texto é de conhecimento popular e parte da identidade nacional do país. Quanto a relação de intertextualidade entre o texto verbal e os não verbais, a produção de sentido conta com estratégias bem exploradas na imagem, que coloca o 'nome fantasia' de diversas marcas/empresas de renome nacional e internacional, construindo um jogo de palavras, por meio da sonoridade entre as palavras e o slogan que populariza as marcas destacadas. Segundo Koch; Bentes; Cavalcante (2012, p. 31), "evidentemente, a entonação em cada uma dessas retomadas não 
ANAIS CBCS 2019 | 3 a 5 de outubro de 2019 | Centro Universitário Santo Agostinho - Teresina - P

só é significativamente diferente da do enunciado de origem, como varia conforme a função da réplica", ao discurso do outro, sobretudo, por meio de sua "adesão" e conhecimento partilhado.

Espera-se que o interlocutor também seja detentor do saber partilhado na produção publicitária. Isso possibilita ao sujeito uma aceitação do contrato que apresenta com clareza uma produção persuasiva de pistas interpretativas para adesão da publicidade. Para o reconhecimento e a produção de sentido entre os dois textos, há uma superposição de códigos verbais e não verbais, mantendo, um relação entre o discurso canônico e nacionalista (hino nacional), constituindo assim, um discurso híbrido, com uma orientação argumentativa e persuasiva.

\section{Intertextualidade implícita em textos verbais (escritos) e textos orais: exemplo III}

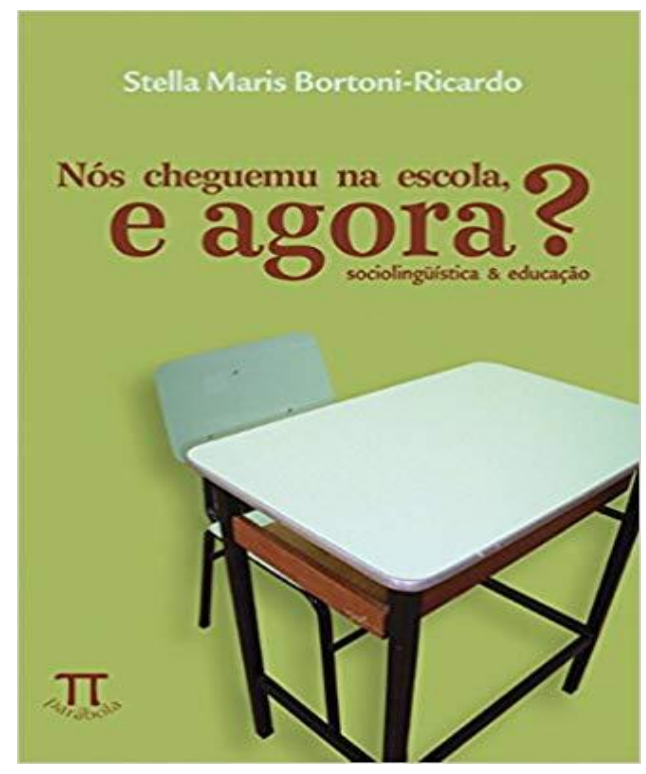

\section{capítulo um}

\section{Heterogeneidade linguística e ensino da língua:} o paradoxo da escola

Quando o professor Paulo Freire foi empossado secretário de educação do município de São Paulo, fez uma declaração que causou estranheza: a de que as professoras não devem criticar ou reprimir um aluno que fale coisas como "nós cheguemu".

O livro "Nós cheguemu na escola, e agora? Sociolinguística \& Educação", lançado pela educadora brasileira Stella Maris Bortoni-Ricardo, editora Parábola, em 2005, traz na capa uma expressão linguística que foge ao padrão normativo e culto da língua portuguesa prestigiada pela escola. Na verdade, ela faz uma crítica à situação de alunos que milhares de escolas espalhadas pelo Brasil, especialmente, as advindas das zonas rurais, de baixa condição econômica e que isso se reflete no seu modo de falar, daí então, questionar-se como a escola estar preparada para lidar com a questão da variação linguística do português brasileiro no contexto da sala de aula. 
ANAIS CBCS 2019 | 3 a 5 de outubro de 2019 | Centro Universitário Santo Agostinho - Teresina - P

No entanto, a "pegada" da autora, com esse título, é uma remissão ao discurso do patrono da educação brasileira, Paulo Freire, em 1989, ao ser empossado secretário da Educação de São Paulo (1989 a 1991), que, ao dirigir-se a um grupo de autoridades e professores, afirmou que estes não deveriam criticar ou reprimir o aluno que fale expressões como "nós cheguemu".

A própria autora (BORTONI-RICARDO, 2005), a partir de seu lugar de pesquisa sociolinguísta educacional - explicita a relação entre o título da obra e o discurso consagrado de Paulo Freire. Embora ela faça isso logo no primeiro capítulo do livro, página 13 (no trecho citado acima, portanto, dispensando-se buscar a referência de Freire, neste caso), para que o leitor compreenda a ideia e "compre a ideia do livro pela capa" é necessário que ele recorra a conhecimentos prévios, acumulados por experiências de mundo, relacionados a história da educação popular no Brasil e ao papel de Paulo Freire como figura de grande representatividade no cenário de desenvolvimento de políticas públicas e estratégias pedagógicas de ensino da língua materna, sobretudo, a alfabetização e o letramento das classes populares, "um verdadeiro mito vivo da pedagogia crítica" (GADOTTI; TORRES, 2001, p. 12) e de esquerda no Brasil.

Freire era o símbolo da mudança educativa que o PT propunha para a população de São Paulo. Ademais, como educador, que viera de um exílio de mais de quinze anos, encontravase em São Paulo, tendo reaprendido o Brasil após regressar e viajar incessantemente, dando palestras, ouvindo o professor, o dirigente sindical e político, o camponês, a mulher trabalhadora, o trabalhador industrial, o morador da favela, o "Gramsci popular" - como ele disse anos atrás a Carlos Alberto Torres. (GADOTTI; TORRES, 2001, p. 12)

A escolha de Bortoni-ricardo (2005) por citar Freire (um dos líderes fundador do maior partida de esquerda do Brasil, o PT), parece hoje bastante controversa e, no mínimo um contrassenso, quando no período de campanha eleitoral de 2018 , a até então, tida como defensora dos menos favorecidos e do seu acesso à escola, por ter uma vasta obra defendendo uma escola democrática e para as classes populares, assumiu publicamente, via redes sociais, uma postura política de direita, apoiando a atual gestão presidencial, que, notoriamente se coloca como inimigo da educação e dos professores. As palavras do também sociolinguística brasileiro, Marcos Bagno 
ANAIS CBCS 2019 | 3 a 5 de outubro de 2019 | Centro Universitário Santo Agostinho - Teresina - P

(UnB), em um ato político no encerramento do XI Congresso Internacional da Associação Brasileira de Linguística (ABRALIN), em 8 de maio de 2019, em Maceió (AL) explicitam a realidade atual:

A cada hora recebemos a informação de que a universidade $X$ só vai poder funcionar até setembro, de que a universidade $Y$ não tem como se manter funcionando depois de agosto, de que a universidade $Z$ vai ter de parar antes de julho. É a asfixia da educação, é o bombardeio da ciência, é a rejeição pura e simples da civilização, nada menos do que isso. Eu não tenho notícia de ter existido jamais ao longo da história um governo que tenha feito da educação a sua inimiga primordial. Mesmo os governos que não se empenharam em favor da educação eram hipócritas e demagógicos e, pelo menos no discurso, faziam o louvor da educação. Mas o desgoverno atual é tão bisonho, tacanho, tosco e burro que não é capaz nem sequer de cinismo. É a brutalidade em seu estado mais insano.

Sem mais imersões ou críticas a postura política assumida por qualquer um dos três pesquisadores (FREIRE; BORTONI-RICARDO; BAGNO), registre-se esse aspecto, apenas como um ponto fulcral para que se pense, de forma crítica e reflexiva, a relação entre educação e política, pois como bem nos ensinou Geraldi (2012 [1984], p. 40) ser professor, especialmente de Língua Portuguesa, implica em tomada de decisões ideológicas, pois "toda e qualquer metodologia de ensino articula uma opção política - que envolve uma teoria de compreensão e interpretação da realidade", bem como "uma concepção de linguagem quanto uma postura relativamente à educação" (p. 41). Política e educação (FREIRE, 2000 [1985]), estão intrinsecamente ligadas, como vemos facilmente em uma rápida anamnese aos registros da história da educação brasileira recente.

\section{Intertextualidade implícita em textos verbais e não verbais: exemplo IV}

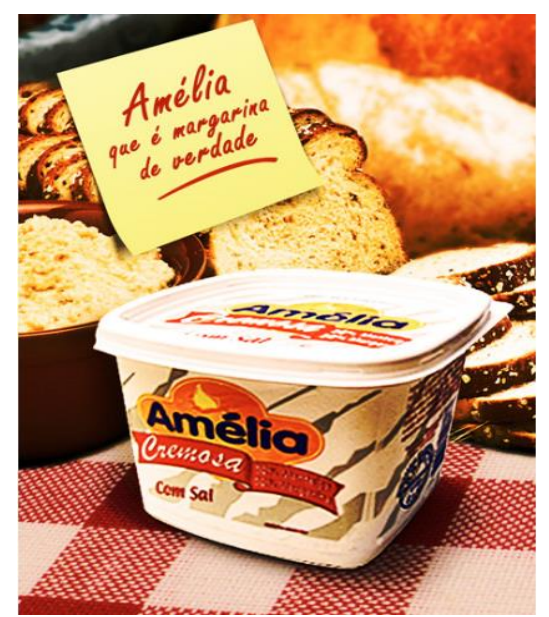

Trecho da música: Ai que Saudades da Amélia

Composição: Ataulpho Alves \& Mário Lago Interpretado por Roberto Carlos

"Amélia não tinha a menor vaidade. Amélia é que era mulher de verdade". 


\section{CONQEEESSO CIENCIASSOCIEDADE

ANAIS CBCS 2019 | 3 a 5 de outubro de 2019 | Centro Universitário Santo Agostinho - Teresina - PI

O nome Amélia em um anúncio publicitário com essa mensagem (Amélia que é margarina de verdade), remete ao clássico de música popular brasileira: "Ai que saudades da Amélia" composta por Ataulpho Alves \& Mário Lago, em 1941, e interpretada por diversos cantores, dentre eles, Roberto Carlos, em 1967. Isso ocorre, porque a letra da música faz parte do repertório linguístico implícito de qualquer brasileiro. Neste exemplo, há também um caso de intergêneros, ou seja, o gênero textual propaganda recorre ao gênero música, para transmitir a sua mensagem.

Vale lembrar, que embora um clássico à sua época, o que é impossível de não ser reconhecido, atualmente, a partir dos movimentos feministas e os estudos que advogam a igualdade de direitos entre os gêneros, a canção de Ataulpho Alves \& Mário Lago é considerada como extremamente machista e repressora ao papel da mulher na sociedade do século XXI.

\section{CONSIDERAÇÕES FINAIS}

O investimento nas breves análises aqui empreendidas, revelam, no geral, que:

Cada texto constitui uma proposta de significação que não está inteiramente construída. A significação se dá no jogo de olhares entre o texto e seu destinatário. Este último é um interlocutor ativo no processo de significação, na medida em que participa do jogo intertextual tanto quanto o autor. (PAULINO; WALTY; CURY, 2005, p. 15)

Acreditamos, particularmente, que o texto é um objeto, uma intenção, uma possibilidade de interação, que só se concretiza, e, se torna de fato um texto, em seu sentido dialógico e responsivo, quando chega às mãos de um leitor, que, de maneira ativa, o recepciona, abre as portas de sua cognição para que a intenção do autor adentre, tome lugar e possa, de fato, construir um sentido. Assim, aquilo que o autor escreve é apenas uma possibilidade de 'texto'. Ele só passa a sê-lo nas mãos de um leitor, que o aceita e dá vida em diferentes esferas interativas.

No caso das relações de intertextualidade, a explicitação, ou não, da fonte dos textos, é, no geral, uma opção do autor, e, em cada esfera de atividade humana - jornalística, científica, jurídica, 
ANAIS CBCS 2019 | 3 a 5 de outubro de 2019 | Centro Universitário Santo Agostinho - Teresina - PI

educacional, acadêmica etc. - esses processos assumem instâncias de valor, autoria e respaldo, de maneiras diferenciadas, conforme os propósitos comunicativos pretendidos e a aceitação do leitor.

No jogo de palavras, vozes, discursos, entonações, cores, efeitos e sentidos que a intertextualidade envolve, é possível inclusive, quanto a sua a constituição, considerarmos que ela também constitui uma espécie de intergenericamente, ou seja, "modelos cognitivos de contexto", segundo Van Dijk $(1994,1997)$ apud Koch; Elias $(2012$, p. 114) para elucidar a questão. Neste caso, como vimos nos exemplos aqui analisados, a produção textual é feita obedecendo ao mesmo gênero do texto de origem, de referência. Em outro não, há uma fuga ou distanciamento, seja do gênero, ou mesmo da modalidade da língua (oral ou escrita), o que já nos remete ao fenômeno da retextualização, tratado por Marcuschi (2010) e que cabe aludirmo-los aqui, em virtude de que tratamos sobre processos de leitura e escrita.

A produção de texto é um processo contínuo. A todo o momento, estamos produzindo enunciados comunicativos, construídos sempre a partir de outros, que lemos, ouvimos ou escrevemos e foram se entranhando em nosso repertório de produtores de textos (orais ou escritos). A identificação desta relação entre os textos se dá pela familiaridade que leitor tem com variados tipos de texto, com o "manuseio" de diferentes modalidades textuais em seu cotidiano, portanto, acentuamos a importância do estudo e da interação com diferentes gêneros textuais, como forma de ampliar as noções de mundo e de construção e identificação da intertextualidade, sendo que esta deve ser colocada como conteúdo de ensino, através de estratégias, finalidades e significações dentro das abordagens feitas em sala de aula.

De maneira modesta, os resultados deste trabalho, estruturado a partir de pesquisas a várias fontes, denota a forma como a intertextualidade é um fenômeno presente em nossos cotidiano, em diferentes situações comunicativas. Percebe-se que a construção de texto, seja oral ou escrita, sempre remete a uma expressão ou a um determinado fato (texto-fonte), mostrando-se familiar à nossa compreensão. Diante disso, torna-se inegável que em todo discurso há uma intertextualidade, que se dá a partir das relações estabelecidas com os diferentes contextos sociocomunicativos. 


\section{cONGGESSOCIENCIASSOCIEDADE

ANAIS CBCS 2019 | 3 a 5 de outubro de 2019 | Centro Universitário Santo Agostinho - Teresina - PI

\section{REFERÊNCIAS}

ASSIS, Machado de. Esaú e Jacó. Obra Completa. Rio de Janeiro: Nova Aguilar, 1994.

BAKHTIN, Mikhail (VOLOCHINOV, Valentin Nikolaevich). Marxismo e filosofia da linguagem. Trad. Michel Lahud e Yara Frateschi Vieira. 13. ed. São Paulo: Hucitec, 2009.

BAKHTIN, Mikhail. Estética da criação verbal. Trad. Paulo Bezerra. 6. ed. São Paulo: Martins Fontes, 2011.

BAKHTIN, Mikhail. Problemas da poética de Dostoiévski. 5. ed. Trad. Paulo Bezerra. Rio de Janeiro: Forense Universitária, 2013.

BAGNO, Marcos. Texto completo do ato político de encerramento do XI Congresso Internacional da Associação Brasileira de Linguística (ABRALIN), em 8 de maio de 2019, em Maceió (AL), posteriormente publicado na coluna da Hildegard Angel, de 08 de julho de 2019. Disponível em: < http://www.hildegardangel.com.br/category/coluna-da-hilde/ >. Acesso em: 08 set. 2019.

BARROS, Diana L. Pessoa de; FIORIN, José Luiz (Orgs.). Dialogismo, polifonia, intertextualidade. São Paulo: Edusp, 1994.

BORTONI-RICARDO, Stella Maris. Nós cheguemu na escola, e agora? Sociolinguística \& Educação. São Paulo: Parábola, 2005.

CHARTIER, Roger. A aventura do livro: do leitor ao navegador. São Paulo: UNESP, 1998.

FIORIN, José Luiz. Interdiscursividade e intertextualidade. In: BRAIT, B. (Org.). Bakhtin: outros conceitos-chave. 2. ed. São Paulo: Contexto, 2014. p. 161-193.

FREIRE, Paulo. Política e educação: ensaios. 4. ed. São Paulo: Cortez, 2000. [1985].

FREIRE, Paulo. A importância do ato de ler: em três artigos que se completam. 51. ed. São Paulo: Cortez, 2011.

GADOTTI, Moacir; TORRES, Carlos Alberto. Paulo Freire, administrador público: a experiência de Paulo Freire na secretaria de educação da cidade de são Paulo [1989-1991]. In: FREIRE, Paulo. A Educação na cidade. 5. ed. São Paulo: Cortez, 2001. p. 11-17.

GERALDI, João Wanderley. Concepções de linguagem e ensino de Português. In: GERALDI, João Wanderley (Org.). $O$ texto na sala de aula. São Paulo: Anglo, 2012 [1984]. p. 39-46. 


\section{congenESSO CIENCIAESOCIEDADE

ANAIS CBCS 2019 | 3 a 5 de outubro de 2019 | Centro Universitário Santo Agostinho - Teresina - PI

$\mathrm{KOCH}$, Ingedore G. Villaça. A intertextualidade como elemento da textualidade. Cadernos PUC 22: Linguística Textual, Texto e Leitura.p. 39- 46, 1986.

KOCH, Ingedore G. Villaça; ELIAS, Vanda Maria. Ler e escrever: estratégias de produção textual. 2. ed. São Paulo: Contexto, 2012.

KOCH, Ingedore G. Villaça. Introdução à Linguística Textual: trajetória e grandes temas. 2. ed. São Paulo: Contexto, 2015.

KOCH, Ingedore G. Villaça; BENTES, Anna Christina; CAVALCANTE, Mônica Magalhães. Intertextualidade: diálogos possíveis. 3. ed. São Paulo: Cortez, 2012.

MARCUSCHI, Luiz Antônio. Da fala para a escrita: atividades de retextualização. 10. ed. São Paulo: Cortez, 2010.

PAULINO, Graça; WALTY, Ivete; CURY, Maria Zilda. Intertextualidades: teoria e prática. 6. ed. São Paulo: Formato, 2005. 